Przegląd Badań Edukacyjnych Educational Studies Review

ISSN 1895-4308

nr 19 (2/2014), s. 195-210

METODY ZBIERANIA

I ANALIZY DANYCH

W BADANIACH

EDUKACYJNYCH

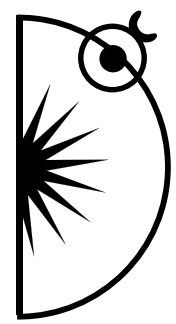

Anna Pierzchała

Akademia im. Jana Długosza w Częstochowie, e-mail: a.pierzchala@ajd.czest.pl

\title{
Eksploracje badawcze funkcjonowania nauczycieli w określonych stanach Ja - przykład próby łączenia podejść ilościowych z jakościowymi
}

DOI: http://dx.doi.org/10.12775/PBE.2014.029

\section{Research on Teachers Functioning in Particular Ego States - an Example of an Attempt to Combine Quantitative and Qualitative Approaches}

\begin{abstract}
The article refers to the concept of transactional analysis, one of modern branches of psychology appreciated not only by psychologists. In consequence, it is applied in different areas of life, such as education. The article explains the notion of "ego state" and the personality structure as defined in the approach in question. There is also a presentation of several egograms constructed in the past, which are used to measure how particular ego states are cathected. They are also used in therapy and research. Moreover, the author presents an egogram for measuring the activation of each ego state in the second order structure. The tool has been used in a number of studies conducted in the area of education, including pedeutology. The author, however, indicates the necessity of results verification through qualitative analysis in such studies.
\end{abstract}

Key words: educational transactional analysis, ego states, the second-order structural model, egogram, quantitative and qualitative approaches in research 


\section{Analiza transakcyjna - teoretyczna podstawa rozważań}

W niniejszym artykule postawiono sobie za cel wskazanie wybranych możliwości eksploracji badawczych funkcjonowania nauczycieli w roli zawodowej, w tym szczególnie zakres wykorzystania przez nich określonych zasobów tkwiących w strukturze osobowości. Charakterystyka przeprowadzona zostanie przy wykorzystaniu jednej ze współczesnych teorii psychologicznych, jaką jest analiza transakcyjna. Koncepcja ta znajduje obecnie coraz szersze zastosowanie także w innych, poza psychologią i psychoterapią, dziedzinach życia, w tym w edukacji. Analiza transakcyjna powstała w latach 50. XX w., a jej twórcą był pochodzący z Montrealu, wykształcony psychoanalitycznie psychiatra - Eric Berne. W 1957 r. po raz pierwszy wskazał on ramy swojej koncepcji, prezentując Amerykańskiemu Towarzystwu Psychoterapii Grupowej tekst zatytułowany Transactional Analysis: A New and Effective Method of Group Therapy (Analiza Transakcyjna: Nowa i Skuteczna Metoda Terapii Grupowej), a następnie pięć lat później, w roku 1962, wydał pierwszą książkę w całości poświęconą jej charakterystyce Transactional Analysis in Psychotherapy (Analiza Transakcyjna w Psychoterapii) (zob. I. Stewart, V. Joines, 2009, s. 284-285). Również w 1962 r. pod redakcją E. Berne'a zaczęto wydawać Transactional Analysis Bulletin (TAB), a już w 1963 r. pojawiły się tam artykuły, w których podejmowano próby przeniesienia i wykorzystania jego założeń na gruncie edukacyjnym. Jednym z pionierów w tej dziedzinie był S. Soles, który analizował różnice i podobieństwa pomiędzy nauczycielem i psychoterapeutą oraz stworzył ramy roli nauczyciela w nurcie analizy transakcyjnej, a także zajął się analizą gier transakcyjnych w klasie szkolnej (za: Emmerton, 2004, s. 283). Obecnie koncepcja analizy transakcyjnej jest szeroko rozwijana głównie w Stanach Zjednoczonych i Europie Zachodniej, ale staje się także coraz popularniejsza w Polsce oraz na wschodzie Europy. Na gruncie międzynarodowym funkcjonują dwa główne stowarzyszenia zajmujące się rozwojem i rozpowszechnianiem koncepcji oraz koordynacją działań jej praktyków i teoretyków. Są to: Międzynarodowe Towarzystwo Analizy Transakcyjnej (International Transactional Analysis Association - ITAA) oraz Europejskie Towarzystwo Analizy Transakcyjnej (European Association for Transactional Analysis - EATA).

W tym miejscu warto więc przynajmniej ogólnie nakreślić, czym jest ana-

liza transakcyjna. Sam twórca definiował ją jako koncepcję funkcjonowania społecznego. Głównym zainteresowaniem przedstawicieli tej koncepcji jest badanie stanów ego, będących spójnymi systemami myśli i uczuć, które manifestują się odpowiednimi zespołami zachowań (Berne, 2005, s. 31). Oznacza to, 
że założenia teorii koncentrują się na funkcjonowaniu jednostki, pojmowanej jako niepowtarzalne indywiduum, w szerszej społeczności. Zachowanie jednego człowieka, które jest w tym ujęciu determinowane przez określony stan Ja, wywołuje odpowiednią reakcję zwrotną innych ludzi, również działających z danych obszarów swojej osobowości. Komunikacja przebiega zatem pomiędzy składowymi ego, których szczegółowa charakterystyka znajduje się w dalszej części opracowania.

\section{Edukacyjna analiza transakcyjna}

Powyżej wspomniano, że analiza transakcyjna powstała jako koncepcja psychologiczna, a konkretniej grupowa metoda pracy psychoterapeutycznej. Jednak wykorzystywanie jej założeń na gruncie innym niż psychologiczny czy terapeutyczny stało się tak istotne, iż w latach 80 . XX w. postanowiono w jej obrębie wydzielić dwa dodatkowe działy - edukacyjnej analizy transakcyjnej, zajmującej się implikacjami pedagogicznymi teorii, oraz organizacyjnej analizy transakcyjnej, w której z powodzeniem wykorzystuje się i rozwija koncepcję w obszarze działań biznesu i zarządzania zasobami ludzkimi. Dla niniejszego opracowania szczególnie istotna jest oczywiście ta pierwsza, gdyż stwarza potencjał wykorzystania jej założeń oraz technik eksploracji badawczych na gruncie edukacji, w tym charakterystyki funkcjonowania nauczycieli w roli zawodowej. W Polsce badania w tym zakresie prowadzi przede wszystkim funkcjonujący na Wydziale Pedagogicznym Akademii im. Jana Długosza Zespół Badawczy Edukacyjnej Analizy Transakcyjnej, którego autorka niniejszego opracowania ma przyjemność być przedstawicielką.

Wskazując możliwe obszary badawcze oraz dotychczasowe dokonania w tej dziedzinie, nie sposób nie wspomnieć przynajmniej podstawowych założeń teoretycznych koncepcji. Naczelnym celem edukacyjnej analizy transakcyjnej jest zatem wykształcenie i/lub wzrost osobowości człowieka, a także jego rozwój w społecznych ramach odniesienia (Emmerton, Newton, 2004, s. 283). Ponownie zatem kładzie się tutaj nacisk zarówno na rozwój jednostki w aspekcie jej podmiotowości, które realizowane jest poprzez odkrywanie i wzmacnianie zasobów własnych, jak i na ćwiczenie kompetencji społecznych człowieka, by umożliwić mu efektywne uczestnictwo w życiu zbiorowym. Jednym $\mathrm{z}$ naczelnych celów rozwoju w tym ujęciu będzie usprawnianie procesu komunikacji, co skutkuje bardziej efektywnymi i satysfakcjonującymi kontaktami z innymi ludźmi. Wynika to przede wszystkim z uświadamiania zasobów tkwiących w człowieku, warunkowanych zarówno wychowaniem, jak i aktyw- 
nością własną jednostki oraz możliwością przeformułowania ograniczeń, jakie w toku rozwoju przyswoiła. Cele szczegółowe edukacyjnej analizy transakcyjnej zawrzeć można natomiast w następujących punktach:

1) stworzenie nowych perspektyw tego, jak ludzie się uczą i tego jak kształcenie może stać się bardziej efektywne;

2) świeże spojrzenie na metody, które aktywizują uczniów, w tym na uczenie się przez doświadczanie, edukację skoncentrowaną na uczniu oraz uczenie, którego kierunek wyznacza uczeń;

3) ćwiczenie radzenia sobie w sytuacjach problemowych;

4) rozwój teorii edukacji bez poczucia winy (blame-free theory), która może uczynić zarówno nauczanie, jak i uczenie się mniej obciążającym z psychologicznego punktu widzenia (Napper, Newton, 2000).

Mając na uwadze zamieszczone powyżej dość ogólne rozważania teoretyczne związane z obranym paradygmatem niniejszego opracowania, należy skoncentrować się na jego podstawowym temacie, jakim są możliwości eksploracji badawczych funkcjonowania nauczycieli w określonych stanach Ja. Rozpocząć trzeba oczywiście od wyjaśnienia, czym są w analizie transakcyjnej stany Ja, a zatem jak wygląda struktura ludzkiej osobowości w tym ujęciu.

Najogólniej rzecz ujmując, struktura osobowości człowieka składa się z trzech głównych obszarów - Ja-Rodzica, Ja-Dorosłego i Ja-Dziecka, które schematycznie przedstawia się, jak na rysunku 1.

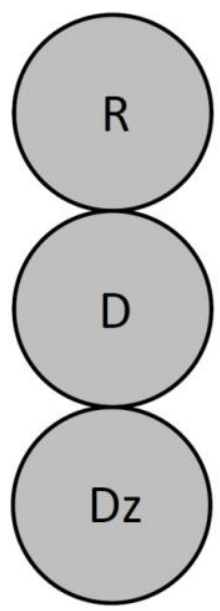

Rysunek 1. Strukturalny diagram osobowości w analizie transakcyjne źródło: E. Berne, 2005, s. 32. 
Stan Ja w analizie transakcyjnej rozumiany jest jako spójny zespół odczuć i doświadczeń bezpośrednio powiązany z odpowiednim wzorcem zachowań (Berne, 2005, s. 507). Każdy ze stanów wywołuje odtworzenie zarejestrowanych w przeszłości informacji dotyczących konkretnych ludzi, czasu, miejsca i uczuć związanych z daną sytuacją (Harris, 1987, s. 32). Każdy z nich jest równocześnie niezbędny do prawidłowego funkcjonowania, a optymalne ich wykorzystanie stwarza możliwość działania autonomicznego, w którym człowiek ma możliwość pełnego wykorzystania własnych zasobów, przy jednoczesnej realnej analizie ograniczeń. Jako pierwszy w ontogenezie powstaje stan Ja-Dziecko. Jego początki sięgają już doświadczeń prenatalnych warunkowanych między innymi nastrojem matki. W Ja-Dziecku zapisane są określone schematy reakcji emocjonalnych, które powstają na podstawie wczesnodziecięcych doświadczeń jednostki. Schematy te kształtują się w odpowiedzi na konkretne sytuacje zaistniałe w tym okresie i wykorzystywane są w życiu dorosłym, często w sposób nieświadomy, w zetknięciu z sytuacją w jakiś sposób zbieżną $\mathrm{z}$ tą dawną. W tym obszarze znajdują zatem wyraz naturalne impulsy, potrzeby, pragnienia, uczucia, a także specyficzny, całościowy i intuicyjny sposób myślenia (Pankowska, 2010, s. 30-31). Dodatkowo w trakcie socjalizacji dziecko poddawane pewnym ograniczeniom uczy się pewnych schematów odczuwania i reagowania emocjonalnego, które także zostają zapisane w tym obszarze.

Drugim powstającym w kolejności obszarem jest Ja-Rodzic. Kształtuje się również w okresie wczesnodziecięcym, ale od momentu narodzin. W nim zapisane są określone sposoby funkcjonowania - myślenia, mówienia, działania - które człowiek przejmuje w sposób bezrefleksyjny od swoich rodziców lub innych osób znaczących z przeszłości. To funkcjonowanie jednostki przyjmuje charakter określonych automatyzmów i uruchamiane jest $w$ reakcji na sytuację w jakiś sposób zbieżną z tą z przeszłości, która go uwarunkowała. Ja-Rodzic zawiera określony zbiór nakazów i zakazów postępowania, które zostały w sposób bezpośredni i pośredni wpojone dziecku, a które prezentuje ono w dorosłym życiu. Co warte podkreślenia, te sposoby myślenia, mówienia czy działania oparte na zbiorze wczesnodziecięcych nakazów i zakazów nie podlegają świadomej i racjonalnej analizie. Dziecko, obserwując rodziców (i inne znaczące osoby), przyjmuje ich przepisy na życie w sposób nieświadomy i bezrefleksyjny. Powodowane to jest jego zależnością i brakiem zdolności do tworzenia znaczeń za pomocą słów. Koduje więc zarówno to, co pozytywne, jak i to, co negatywne, to co spójne, jak i to, co zawiera w sobie wewnętrzne sprzeczności. W Rodzicu mogą więc być zapisane zarówno informacje zupełnie nieracjonalnego myślenia i postępowania, jak i efektywne reakcje na daną sytuację. Istotne jest także, 
że zachowaniu i myśleniu mającemu swe źródło w tym obszarze towarzyszy pewien przymus wewnętrzny.

Powstającym najpóźniej, ale też najbardziej autonomicznym obszarem Ja człowieka jest Dorosły. Zaczyna się on kształtować w momencie, w którym dziecko zaczyna odczuwać i realizować potrzebę samodzielnej eksploracji otaczającego świata, czyli zazwyczaj około dziesiątego miesiąca życia (zob. Jagieła, 2004, s. 96). Jako jedyny też ulega rozwojowi i związanym z nim modyfikacjom do końca życia jednostki. Jego rolą jest zbieranie i analiza informacji oraz podejmowanie decyzji dotyczących reakcji w odpowiedzi na różnorodne dane płynące zarówno z pozostałych dwóch obszarów Ja, jak i z otaczającego świata. Jako jedyny ma szansę rozpoznać zasoby i ograniczenia tkwiące zarówno w Ja-Rodzicu, jak i w Ja-Dziecku oraz racjonalnie ocenić zaistniałą sytuację zewnętrzną. Ze względu na te możliwości czasami jest porównywany do komputera (Harris, 1987, s. 45).

Powyżej zaprezentowano najbardziej ogólny i podstawowy podział struktury osobowości człowieka, który nie jest jednak wystarczający z punktu widzenia niniejszego opracowania. W tym miejscu należy się zatem odwołać do tzw. struktury osobowości drugiego stopnia (zob. Jagieła, 2004, s. 100-102; Pierzchała, 2013, s. 43-46).

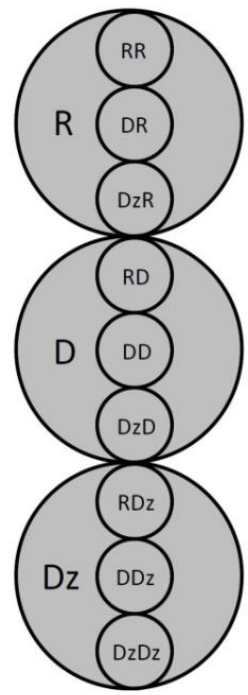

$$
\begin{aligned}
& \text { Gdzie: } \\
& \text { RR - Rodzic w Rodzicu } \\
& \text { DR - Dorosły w Rodzicu } \\
& \text { DzR - Dziecko w Rodzicu } \\
& \text { RD - Rodzic w Dorosłym } \\
& \text { DD - Dorosły w Dorosłym } \\
& \text { DzD - Dziecko w Dorosłym } \\
& \text { RDz - Rodzic w Dziecku } \\
& \text { DDz - Dorosły w Dziecku } \\
& \text { DzDz - Dziecko w Dziecku }
\end{aligned}
$$

Rysunek 2. Strukturalny model struktury osobowości drugiego stopnia Źródło: J. Jagieła, 2004, s. 101. 
Jak wynika z rysunku 2, w strukturze drugiego stopnia każdy z omówionych wcześniej stanów Ja dzieli się na trzy dodatkowe obszary, które należy choćby ogólnie scharakteryzować. Zatem rozpoczynając od góry schematu' ${ }^{1}$ :

- Rodzic w Rodzicu, który zwany jest inaczej Rodzicem Kontrolującym, jest obszarem odpowiedzialnym za wydawanie nakazów i stawianie żądań oraz wydawanie zakazów w kontekście danego zachowania;

- Dorosły w Rodzicu to inaczej Rodzic Praktyczny, który zawiera w sobie przepisy konkretnego zachowania się $\mathrm{w}$ danej sytuacji, odpowiada zatem na pytanie ,jak należy to zrobić”;

- Dziecko w Rodzicu, czyli Rodzic Opiekuńczy, to część Ja, w której zapisane są instynkty opiekuńcze, wychowawcze i pomocowe względem siebie samego i innych ludzi;

- Rodzic w Dorosłym, inaczej Ethos, to obszar odpowiedzialny za racjonalną analizę zapisów tkwiących w strukturze Ja-Rodzic, dzięki czemu możliwe staje się określenie własnych zasobów i ograniczeń z tym związanych;

- Dorosły w Dorosłym, Logos, odpowiedzialny jest za kontakt z otaczającym światem zewnętrznym; ma możliwość odbioru i analizy danych stamtąd płynących oraz podejmowania decyzji, co do sposobu działania;

- Dziecko w Dorosłym, które inaczej zwane jest Pathosem, jest obszarem analogicznym do Ethosu, ale analizującym zapisy tkwiące w strukturze Ja-Dziecko; dzięki niemu możliwe jest rozpoznanie i analiza tkwiących w nim schematów reakcji emocjonalnych;

- Rodzic w Dziecku to inaczej Dziecko Przystosowane, czyli część Ja tworząca się w odpowiedzi na oddziaływania rodzicielskie; reaguje określonymi schematami emocjonalnymi, które „kazali mu” przeżywać rodzice;

- Dorosły w Dziecku, czyli tzw. Mały Profesor, to najbardziej intuicyjna i twórcza część osobowości człowieka, która odkrywa świat poprzez działania, pomijając przy tym racjonalną analizę problemu;

- Dziecko w Dziecku, Dziecko Wolne, to część Ja, którą można by przyrównać do freudowskiego Id - reaguje w sposób nieskrępowany, emocjonalny na aktualne zdarzenia, nie angażując przy tym racjonalnego myślenia.

${ }^{1}$ Analiza zgodna z ułożeniem poszczególnych obszarów na schemacie nie odpowiada oczywiście momentowi ich tworzenia w ontogenezie i prowadzona jest jedynie ze względu na zapewnienie przejrzystości wywodu. Należy jednak pamiętać, że tak jak wyjaśniono wcześniej, pierwszym kształtującym się obszarem jest stan Ja-Dziecko, a dokładniej w przypadku struktury drugiego stopnia, obszar Dziecka w Dziecku, czyli tzw. Dziecko Naturalne. 
Kończąc teoretyczne rozważania na temat stanów Ja, należy wskazać, iż niemal wszystkie one (z wyjątkiem Dorosłego) mają tzw. pozytywne i negatywne aspekty. Oznacza to, że mogą być zarówno przydatne i wartościowe dla funkcjonowania tu-i-teraz, jak i nieefektywne, archaiczne i szkodliwe, ale nadal wykorzystywane.

Umiejętność pewnej autorefleksji i rozpoznania u siebie aktualnego stanu Ja, a także stanu, w którym przebywa partner w relacji stwarza perspektywę efektywnej komunikacji. Każdy człowiek ma bowiem indywidualne predyspozycje do przebywania $\mathrm{w}$ określonym Ja, który można określić jako dominujący. Najbardziej korzystną sytuacją jest dominacja obszaru Ja-Dorosły, który umożliwia realny ogląd zasobów tkwiących w pozostałych obszarach i ich racjonalne wykorzystanie. Warunkuje to zdolność do wzajemnego dopasowania w relacji, co z kolei skutkuje tym, iż interakcja ma szansę przebiegać bez zakłóceń. Oznacza to, że partnerzy potrafią płynnie przechodzić z jednego stanu do drugiego i dopasować jakość komunikacji do zaistniałej sytuacji. Na gruncie edukacyjnym w relacji nauczyciela $z$ uczniem jest to o tyle istotne, iż z jednej strony stwarza płaszczyznę porozumienia przy obopólnym zadowoleniu obu stron, a z drugiej daje nauczycielowi konkretne narzędzie pomagające rozwijać u ucznia obszar Ja-Dorosłego, co stanowi jeden z naczelnych celów edukacyjnych. Ja-Dorosły stanowi bowiem podstawę autonomicznego funkcjonowania człowieka oraz wyposaża w zdolność realnej oceny rzeczywistości oraz własnych możliwości.

\section{Egogram jako narzędzie analizy funkcjonowania jednostki w określonych stanach Ja}

W analizie transakcyjnej przyjmuje się, że poszczególne obszary osobowości człowieka manifestują się w sposób behawioralny. Oznacza to, że nie są one jedynie czystymi konceptami teoretycznymi, co z kolei wskazuje na to, że poddają się badaniom empirycznym. Narzędziem do tego wykorzystywanym na gruncie działalności badawczej jest tzw. egogram, czyli kwestionariusz służący pomiarowi zakresu kateksjonowania (uaktywniania, aktywizowania) poszczególnych obszarów Ja wraz z graficzną prezentacją rozkładu wyników. Egogramy przedstawiają zatem intensywność i częstotliwość bodźców dochodzących $\mathrm{z}$ danego stanu Ja. W terapii umożliwia to przeprowadzenie analizy funkcjonowania pacjenta z poziomu Ja-Dorosły (Dusay, 1972, s. 38). W niniejszym opracowaniu charakterystyce poddane zostanie jedno z narzędzi tego typu, które z powodzeniem było i jest wykorzystywane na gruncie edukacyjnej analizy 
transakcyjnej, w tym do badania funkcjonowania nauczycieli. Narzędziem tym jest Egogram Strukturalny. Kwestionariusz Samooceny Stanów Ja autorstwa A. Pierzchały i A. Sarnat-Ciastko (Pierzchała, Sarnat-Ciastko, 2011, s. 280-281; Pierzchała, 2013, s. 135-138 i in.). Aczkolwiek jego charakterystykę rozpocząć należy od inspiracji płynących z innych narzędzi tego typu funkcjonujących na polskim gruncie oraz uzasadnienia, dlaczego autorki zdecydowały się na stworzenie kwestionariusza nowego, rezygnując z wykorzystania już istniejących.

Pierwsze narzędzie typu egogram zostało skonstruowane przez J. M. Dusaya już w latach 70. XX w. Jest ono dostępne w polskiej wersji językowej i z powodzeniem wykorzystywane w terapii i w analizach doradczych na gruncie głównie organizacyjnej analizy transakcyjnej (zob. Kälin, 1998, s. 38-53). $\mathrm{Z}$ punktu widzenia badań naukowych ma jednak kilka wad, wśród których należy wymienić przede wszystkim brak standaryzacji, a także zdychotomizowanie możliwych odpowiedzi na dane twierdzenia kwestionariusza (możliwość odpowiedzi jedynie „tak"/"nie”), czyli pomiar o charakterze nominalnym, który nie uprawnia do zastosowania zbyt wielu analiz statystycznych. Pewnym ograniczeniem w badaniach jest też długość kwestionariusza - 143 itemy - co przy próbie zastosowania badań korelacyjnych, w których istnieje konieczność określenia dodatkowej/dodatkowych zmiennych, również z wykorzystaniem kwestionariusza/kwestionariuszy, może obniżać rzetelność pomiaru ze względu na zmęczenie respondenta. Nie zmienia to jednak faktu, że Egogram J. M. Dusaya już od wielu lat funkcjonuje jako wzorzec narzędzi tego typu i stał się również jedną z głównych inspiracji Egogramu Strukturalnego.

Poza tłumaczeniem opisanego powyżej narzędzia, na polskim gruncie stworzonych zostało jeszcze kilka kwestionariuszy. I tak w obszarze terapeutycznym analizy transakcyjnej, czyli głównie na potrzeby terapii, opracowany został Kwestionariusz Egogramu Teresy Samek (1993, s. 87-94). Na gruncie organizacyjnym funkcjonuje Kwestionariusz Stylów Osobistych Ewy Szymanowskiej i Magdaleny Sękowskiej (2000, s. 37-39). Kilka ciekawych propozycji powstało też i było wykorzystywanych w badaniach edukacyjnych - warto tu wymienić takie propozycje, jak: Mapa Dorostego Zbigniewa Wieczorka (1997, s. 186-190) i zbudowany na podstawie narzędzia T. Samek Kwestionariusz Egogram Agnieszki Bardzińskiej, Anny Chaber, Zbigniewa Łęskiego (1997, s. 181-185). Jednak wymienione powyżej narzędzia nie doczekały się, niestety, standaryzacji. Szczególnego podkreślenia warte są dwa narzędzia, również powstałe w obrębie edukacyjnej analizy transakcyjnej - Szkolna codzienność nauczycieli Doroty Pankowskiej (2010, s. 371-376) oraz Egogram EFP Jarosława Jagieły (2011, s. 274-277). Pierwszy z nich został częściowo wystan- 
daryzowany i z powodzeniem zastosowany w szeroko zakrojonych badaniach pedeutologicznych, charakteryzujących rzeczywistość pracy nauczycielskiej z punktu widzenia analizy transakcyjnej (Pankowska, 2010). Drugi natomiast podlega właśnie częściowej standaryzacji w ramach prac wspomnianego wcześniej Zespołu Badawczego Edukacyjnej Analizy Transakcyjnej i stanowi ciekawą alternatywę dla wszystkich wymienionych tutaj narzędzi. Wszystkie one opierają się bowiem na stwierdzeniach, których prawdziwość względem siebie respondent określa na skali Likerta. W przypadku Egogramu EFP inspirację zaczerpnięto z Testu Przymiotnikowego ACL i podjęto próbę przyporządkowania przymiotników do określonego obszaru Ja w strukturze osobowości człowieka.

Należy jednak wyjaśnić, dlaczego pomimo tak wielu funkcjonujących i sprawdzających się egogramów podjęto kolejne wyzwanie i opracowano Egogram Strukturalny. Otóż istniały ku temu dwie główne przesłanki. Po pierwsze, autorki postanowiły stworzyć narzędzie, które jako pierwsze odwołuje się do analizy osobowości drugiego stopnia, opisanej w pierwszej części artykułu. Pozostałe kwestionariusze dają bowiem możliwość określenia tzw. struktury funkcjonalnej, która w obszarze Ja-Rodzic wymienia jedynie Rodzica Kontrolującego i Opiekuńczego, a w obszarze Ja-Dziecko - Dziecko Przystosowane i Wolne, natomiast Ja-Dorosły w tym ujęciu pozostaje niepodzielny. Po drugie, egogramy te arbitralnie przyporządkowują dane stwierdzenie do kategorii ,pozytywny/negatywny aspekt danego stanu Ja". Natomiast autorki nowego narzędzia umożliwiły badanym dokonanie samooceny, poprzez wyrażenie własnego (subiektywnego) zdania dotyczącego tego, na ile dany stan Ja ma znaczenie w ich własnym życiu. Pozwoliły także na określenie jego pozytywnych lub negatywnych konotacji. Wyszły tym samym naprzeciw argumentom badaczy, którzy twierdzą, iż owe podziały pozostają umowne i indywidualne. W podejściu tym sugeruje się jedynie, że negatywne stany to te, które na tu-i-teraz nie są traktowane przez badanych jako walor w ich życiu, w odróżnieniu do stanów pozytywnych (zob. Stewart, Joines, 2009, s. 24-26). Całe narzędzie wraz z instrukcją znaleźć można w publikacji Pasywność w szkole (Pierzchała, 2013), tutaj jednak warto przyjrzeć się przynajmniej jego ogólnej konstrukcji (rys. 3).

Stwierdzenia dotyczące kateksjonowania poszczególnych obszarów Ja są zatem oceniane standardowo na skali Likerta. Dodatkowo jednak każde twierdzenie analizowane jest pod kątem wartości danej cechy dla respondenta, co umożliwia stworzenie profilu aspektów pozytywnych i negatywnych danych stanów. Jest to bezsprzecznie element wykorzystywany w badaniach o charakterze jakościowym, który tutaj został uwzględniony w kwestionariuszu charakterystycznym dla analiz ilościowych. 
Poniżej znajduje się szereg zdań opisujqcych przykładowe zachowania i poglądy. Proszę Paniq/Pana o odniesienie ich do swojej osoby na dwa sposoby - po pierwsze, czy dana sytuacja jest prawdziwa w Pani/Pana przypadku i po drugie, czy uważa to Pani/Pan za swoja pozytywna czy negatywna cechę. Przy każdym twierdzeniu należy zatem postawić dwa symbole „X”, zarówno w prążkowanej, jak i jednolitej, ciemnej kolumnie, tak jak w przykładzie poniżej:

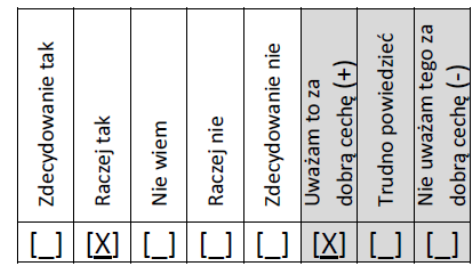

\section{TWIERDZENIA}

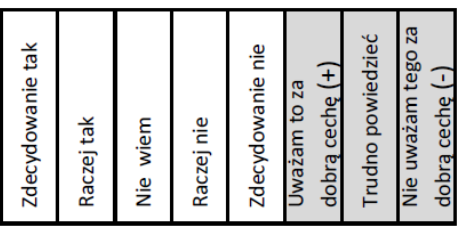

1. Coraz to częściej uważam, że to ja mam rację, a nie inni.

2. Jestem za przestrzeganiem ustalonych wcześniej procedur działania.

3. Jestem osobą, która potrafi się poświęcać.

4. Mam swoje przekonania, ale rozsądne argumenty są w stanie je zmienić.

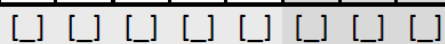

Działam raczej rozumem niż sercem.

6. Potrafię powiedzieć "nie” tak, żeby nie urazić innej osoby, jeśli nie mam ochoty podejmować się jakichś zadań.

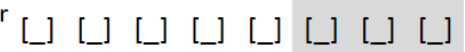

Lubię, jak ktoś powie mi, co mam robić.

8. Pasja w moim życiu jest najważniejsza.

9. Pokazuję uczucia bez skrępowania, nie wstydząc się ich.

10. W dzieciństwie nauczyłam/-łem się pewnych schematów postępowania i nadal w zgodzie z nimi funkcjonuję.

11. Widząc czyjeś nieszczęście, zawsze reaguję.

Rysunek 3. Egogram Strukturalny. Kwestionariusz Samooceny Stanów Ja (A. Pierzchała, A. Sarnat-Ciastko) - fragment

Źródło: A. Pierzchała, 2013, s. 354-355.

Narzędzie w trakcie procesu tworzenia zostało poddane częściowej standaryzacji ${ }^{2}$ - określono jego trafność wewnętrzną dzięki opiniom zespołu sędziów

${ }^{2}$ Całość procesu weryfikacji oraz poszczególne współczynniki rzetelności i mocy dyskryminacyjnej zaprezentowane zostały w książce Pasywność w szkole (Pierzchała, 2013, s. 135-138 i 354-358). 
kompetentnych, wyznaczono rzetelność (współczynnik $\alpha$-Cronbacha; wartość $>0,7$ dla każdej ze skal) oraz moc dyskryminacji testu (współczynnik rbi). Aktualna wersja liczy 45 itemów.

Konstrukcja narzędzia oraz zastosowanie procedury weryfikacyjnej umożliwiły efektywne zastosowanie go w badaniach edukacyjnych, a w tym pedeutologicznych. Autorka niniejszego artykułu wykorzystała je w badaniach na temat pasywności szkolnej ${ }^{3}$, w których między innymi analizowany był zakres stosowania poszczególnych, wymienianych $\mathrm{w}$ analizie transakcyjnej, strategii pasywnych, w zależności od stopnia kateksjonowania poszczególnych obszarów Ja (Pierzchała, 2013). W badaniu udział wzięli zarówno uczniowie (333 osoby), jak i nauczyciele (211 osób). Obecnie realizowanych jest kilka projektów (w różnym stopniu zaawansowania), w których również wykorzystuje się opisywane narzędzie. Są to badania A. Sarnat-Ciastko na temat tutoringu w polskim systemie oświaty, gdzie szczegółowo analizowane są efekty jego stosowania zarówno dla uczniów, jak i nauczycieli, a także, tej samej autorki, analizy dotyczące gotowości do podejmowania współpracy z ludźmi; badania D. Gębuś dotyczące twórczego podejścia do sytuacji problemowych; E. Widawskiej na temat podejmowania działań animacyjnych w środowisku lokalnym, Z. Wieczorka analizujące związek pomiędzy strukturą osobowości a zachowaniami asertywnymi i aktywnością własną badanych oraz Z. Łęskiego charakteryzujące formy i sposoby korzystania z komputera, w zależności od zakresu uaktywniania poszczególnych obszarów Ja. Autorka niniejszego opracowania także jest obecnie w trakcie realizacji kolejnego projektu, którego częścią jest opisywany egogram. Badania te mają charakter pedeutologiczny i dotyczą nauczycielskiej perspektywy niepowodzeń szkolnych uczniów. Na Wydziale Pedagogicznym Akademii im. J. Długosza w Częstochowie narzędzie to wykorzystywane jest także przez studentów w badaniach będących podstawą prac dyplomowych. Przykładem niech będzie praca na temat zakresu kateksjonowania obszaru Ja-Dziecko przez artystów muzyków, gdzie narzędzie to zostało nieco zmodyfikowane i dostosowane do potrzeb badań (Rodasik, 2013).

${ }^{3}$ Pasywność w analizie transakcyjnej rozumiana jest inaczej, szerzej niż w standardowym jej rozumieniu. Jest sposobem myślenia i działania, który umożliwia jednostce uniknięcie autonomicznej reakcji w obliczu sytuacji problemowej. Ujawnia się w momencie, w którym człowiek w obliczu problemu zaprzestaje aktywności bądź staje się nieefektywny. Pasywność może więc zatem manifestować się tutaj także w działaniu, a przejawia się przez cztery strategie - bierność, nadadaptację, niepohamowanie oraz ostatnią strategię posiadającą dwie manifestacje: agresję lub niezdolność. Ich szersza charakterystyka przekracza jednak ramy niniejszego opracowania, stąd zostanie pominięta. 


\section{Analizy ilościowo-jakościowe jako wyraz „metodologicznej trzeciej drogi" w dążeniu do wielowymiarowego spojrzenia w badaniach społecznych}

Warto jednak w tym miejscu powiedzieć o pewnych ograniczeniach związanych $\mathrm{z}$ zastosowaniem narzędzi typu egogram $\mathrm{w}$ badaniach naukowych, $\mathrm{w}$ tym tych realizowanych na gruncie edukacyjnym. Refleksje te są rezultatem wspomnianych już badań na temat pasywności szkolnej. Otóż eksploracje te prowadzone były przy wykorzystaniu zarówno technik ilościowych, których przykładem jest właśnie opisywany tutaj egogram, jak i jakościowych - na podstawie pogłębionych wywiadów z uczniami i ekspertami instytucjonalnymi. Przypomnieć należy także, że w badaniu ilościowym (opartym na kwestionariuszach) udział wzięli zarówno uczniowie, jak i nauczyciele. Uzyskano wiele inspirujących i ciekawych wyników wskazujących na statystyczne zależności pomiędzy określonym zakresem kateksjonowania poszczególnych obszarów Ja a stosowaniem pasywności. Zależność pomiędzy pasywnością a funkcjonowaniem nauczycieli w określonych stanach Ja określono jednoczynnikowym testem ANOVA przy założonym poziomie istotności $p<0,05$, wcześniej potwierdzając normalność rozkładu zmiennych. Za czynnik grupujący przyjęto pasywność we wszystkich jej przejawach, wyznaczając jej poziom niski, średni i wysoki. W przypadku nauczycieli najdonioślejsze znaczenie ma zakres uaktywniania stanu Ja-Dorosły we wszystkich jego przejawach. Przy czym zależność ta wygląda w ten sposób, że ograniczenie funkcjonowania w Etosie, Logosie czy Pathosie sprzyja wyższemu poziomowi pasywności. Istotny jest także zakres kateksjonowania Dziecka Przystosowanego, przy czym w tym przypadku zależność wygląda odwrotnie - wyższemu zakresowi energetyzowania tego obszaru towarzyszy wyższy poziom pasywności. Sprzyja jej także znaczne rozpoznanie negatywnych aspektów Dziecka Przystosowanego oraz Rodzica Opiekuńczego ${ }^{4}$.

Aczkolwiek należy pamiętać, że narzędzia typu egogram zawsze mają charakter deklaratywny, a w związku z tym rzetelne ich wypełnienie przez respondenta warunkowane jest dobrze rozwiniętym stanem Ja-Dorosły. Braki w tym obszarze warunkują raczej nakreślenie obrazu ,ja-idealnego" niż ,ja-realnego", co należy uwzględnić w interpretacji tego rodzaju wyników badań. Konieczne wydaje się zatem zastosowanie określonych technik zapobiegających

${ }^{4}$ Przytoczone wyniki badań mają charakter orientacyjny i wskazują jedynie przykładowy obszar eksploracji badawczych. Czytelnika zainteresowanego szerszym kontekstem wspomnianych badań odsyłam do publikacji Pierzchała, 2013. 
zniekształceniom. Z jednej strony może to być przygotowanie respondenta do wypełnienia tego rodzaju kwestionariusza przez wyjaśnienie mu podstaw koncepcji oraz udział w zajęciach introspekcyjnych, które pozwolą w miarę obiektywny sposób oceniać własne możliwości i ograniczenia. Tak właśnie zazwyczaj dzieje się na gruncie terapeutycznym. W szeroko zakrojonych badaniach społecznych jest to oczywiście trudniejsze do przeprowadzenia ze względu na liczebność próby badawczej. Pomocne w tym zakresie mogą się jednak okazać analizy o charakterze jakościowym, co zostało dowiedzione we wspomnianym powyżej projekcie. Badania te zostały bowiem uzupełnione o pogłębione wywiady z uczniami i ekspertami instytucjonalnymi (psychologami i pedagogami stale współpracującymi z uczniami i nauczycielami). W ich wyniku ukazał się nieco inny, pogłębiony obraz funkcjonowania nauczycieli, który pomógł wyjaśnić mechanizmy powstawania pasywności. W odniesieniu do struktury osobowości wspomnieć tutaj można chociażby kwestię związaną z dość powszechnym hamowaniem przez nauczycieli stanu Ja-Dziecko, szczególnie w obszarze Dziecka Wolnego, co skutkuje próbami wchodzenia w relacje z uczniami z pozycji Rodzica Kontrolującego, a często jest wynikiem braku zaufania do własnych możliwości i kompetencji oraz lęku przed utratą kontroli.

Ponieważ celem każdego badacza powinno być dążenie do możliwie dokładnego wyjaśnienia analizowanych zjawisk, wydaje się, że wykorzystanie w badaniach tzw. metodologicznej trzeciej drogi i podjęcie próby pogodzenia technik ilościowych z jakościowymi jest możliwe i słuszne (zob. Flick, 2011, s. 33). Poszukanie możliwości połączenia tych odmiennych podejść stwarza szansę na uwiarygodnienie wyników oraz bardziej wielowymiarowe spojrzenie na badane kwestie, co sprzyjać będzie przybliżeniu się do obiektywnej prawdy. Analiza transakcyjna jako pewna alternatywa w badaniach, także edukacyjnych, stwarza takie możliwości i wydaje się zarówno konceptem, jak i narzędziem godnym zainteresowania badaczy.

\section{Bibliografia}

Bardzińska A., Chaber A., Łęski Z. (1997), Kwestionariusz Egogram (wersja eksperymentalna), [w:] J. Jagieła (red.), Analiza transakcyjna w teorii i praktyce pedagogicznej, Wydawnictwo Wyższej Szkoły Pedagogicznej, Częstochowa.

Berne E. (2005), Dzień dobry... i co dalej?, REBIS, Poznań.

Dusay J. M. (1972), Egograms and the “Constancy Hypothesis”, „Transactional Analysis Journal", vol. 2, no. 3 . 
Emmerton N., Newton T. (2004), The Journey of Educational Transactional Analysis from Beginnings to the Present, „Transactional Analysis Journal”, vol. 34, no. 3.

Flick U. (2011), Projektowanie badania jakościowego, WN PWN, Warszawa.

Harris T. A. (1987), W zgodzie z tobq i z sobq, Instytut Wydawniczy PAX, Warszawa.

Jagieła J. (2011), Egogram EFP (wersja eksperymentalna), [w:] J. Jagieła (red.), Analiza transakcyjna w edukacji, Wydawnictwo im. Stanisława Podobińskiego Akademii im. Jana Długosza w Częstochowie, Częstochowa.

Jagieła J. (2004), Gry psychologiczne w szkole, OWN, Kielce.

Kälin K. (1998), Analiza transakcyjna na co dzień, [w:] K. Kälin, P. Müri (red.), Kierować sobq i innymi. Psychologia dla kadry kierowniczej, Wydawnictwo Profesjonalnej Szkoły Biznesu, Kraków,

Napper R. (2000), Newton T., Tactics - Transactional analysis concepts for all trainers, teachers and tutors + insight into collaborative learning strategies, Ipswich, UK: TA Resources.

Pankowska D. (2010), Nauczyciel w perspektywie analizy transakcyjnej, Wydawnictwo Uniwersytetu Marii Curie-Skłodowskiej, Lublin.

Pierzchała A. (2013), Pasywność w szkole. Diagnoza zjawiska z punktu widzenia analizy transakcyjnej, Wydawnictwo im. Stanisława Podobińskiego Akademii im. Jana Długosza w Częstochowie, Częstochowa.

Pierzchała A., Sarnat-Ciastko A. (2011), Egogram strukturalny. Kwestionariusz samooceny stanów Ja (wersja eksperymentalna), [w:] J. Jagieła (red.), Analiza transakcyjna w edukacji, Wydawnictwo im. Stanisława Podobińskiego Akademii im. Jana Długosza w Częstochowie, Częstochowa.

Rodasik J. (2013), Struktura Ja-Dziecko w osobowości artystów muzyków, niepublikowana praca magisterska napisana pod kierunkiem dra Z. Łęskiego, Częstochowa.

Samek T. (1993), Analiza transakcyjna, Centrum Terapii Alkoholizmu, Wydawnictwo Zakonu Pijarów, Kraków.

Soles S., (1963), Social dynamics. A study of clasroom games - Progress report, „Transactional Analysis Bulletin”, 2 (8), s. 97, za: N. Emmerton, T. Newton (2004), The Journey of Educational Transactional Analysis from Beginnings to the Present, „Transactional Analysis Journal”, vol. 34, no. 3.

Stewart I., Joines V. (2009), TA Today. A New Introduction to Transactional Analysis, Lifespace Publishing, Nottingham, England and Chapel Hill, North Carolina, USA.

Szymanowska E., Sękowska M. (2000), Analiza transakcyjna w zarządzaniu, Wydawnictwo Profesjonalnej Szkoły Biznesu, Kraków. 
